\title{
PRZESŁANKI ZAWARCIA MALŻEŃSTWA W PRAWIE POLSKIM I FRANCUSKIM: ANALIZA SEMANTYCZNO-SKŁADNIOWA
}

\author{
Paulina MAZURKIEWICZ, dr \\ Katolicki Uniwersytet Lubelski Jana Pawła II \\ Instytut Filologii Romańskiej \\ Al. Racławickie 14 \\ 20-950 Lublin \\ mazurkiewicz.paulina@gmail.com
}

\section{PRZESLANKI ZAWARCIA MALŻEŃSTWA W PRAWIE POLSKIM I FRANCUSKIM: ANALIZA SEMANTYCZNO-SKŁADNIOWA}

Cel niniejszego artykułu stanowi porównawcze studium, w aspekcie semantyczno-składniowym, desygnacji przesłanek zawarcia małżeństwa w prawie polskim i francuskim. W obu systemach prawnych, dzielą się one zasadniczo na trzy kategorie: warunkujące, formalne i wykluczające. Analizy, wpisujące się w prace nad terminologią prawa polskiego i francuskiego, jasno ukazują podobieństwa i różnice w konceptualizacji przesłanek. Prawo polskie zezwala na równorzędność formy świeckiej i wyznaniowej zawierania małżeństwa; z kolei prawo francuskie zezwala na zawarcie małżeństwa osób tej samej płci (mariage homosexuel) lub małżeństwo w wypadku nieobecności jednego z przyszłych małżonków (mariage posthume). Podejmowane prace uzasadniają uznanie onomazjologii i semazjologii jako nierozłącznych metod analizy terminologicznej.

\section{REQUIREMENTS FOR MARRIAGE IN POLISH AND FRENCH LAW: SEMANTIC AND SYNTACTIC ANALYSIS}

The objective of this article is to compare semantic and syntactic designation of requirements for marriage in Polish and French law. In both jurisdictions they generally fall into three categories: conditioning, formal and exclusive. The analyses of the terminology pertaining to French and Polish marriage law have exposed similarities and differences in conceptualisation of requirements for marriage. The Polish law allows both of the religious and secular marriage. By contrast, the French law allows for same-sex marriage (mariage homosexuel) and marriage in the event of the absence of one of the future spouses (mariage posthume). The present research has also proved the usefulness of onomasiology and semasiology as combined methods of terminological analysis. 


\section{LES CONDITIONS DU MARIAGE DANS LE DROIT POLONAIS ET LE DROIT FRANÇAIS : ANALYSE SEMANTIQUE ET SYNTAXIQUE}

L'objectif du présent article est de comparer, dans la dimension sémantique et syntaxique, la désignation des conditions du mariage dans le droit polonais et le droit français. Dans les deux systèmes juridiques, elles se répartissent en trois catégories : nécessaires, formelles et exclusives. Les analyses s'inscrivant dans les travaux sur la terminologie du droit polonais et du droit français démontrent les ressemblances et les dissemblances dans la conceptualisation des conditions. Le droit polonais permet la forme laïque et religieuse de la célébration du mariage, par contre, le droit français permet le mariage entre les personnes du même sexe (mariage homosexuel) ou le mariage dans le cas de l'absence d'un des futurs époux (mariage posthume). Les travaux entrepris justifient la reconnaissance de l'onomasiologie et de la sémasiologie comme méthodes inséparables de l'analyse terminologique.

\section{Wstęp}

Niniejszy artykuł wpisuje się w szeroko pojęte badania nad terminologią jako dziedziną językoznawstwa zajmującą się badaniem języków specjalistycznych, w tym języka prawa rozumianego tutaj jako kategoria zawierająca w sobie język prawny i prawniczy. W naszych pracach skupiamy się na teorii terminologii z uwzględnieniem różnorodności podejść prezentowanych w krajach frankofońskich, przede wszystkim we Francji i w Kanadzie (Mazurkiewicz 2012, 283-285). Głównym założeniem, które jest przyjęte do badań jest to, że w/w języki są głęboko zakorzenione w rzeczywistości prawnej właściwego dla danego narodu, a wymiar leksykalno-składniowy terminów wyraża sposób pojęciowania charakterystyczny dla systemu prawnego polskiego i francuskiego (Gałuskina, Mazurkiewicz 2013, 118-120).

Przesłanki określane są w prawie jako warunki, które muszą być spełnione, aby można było zawrzeć małżeństwo (Siedlecki, Świeboda 2000, 74). Punktem wyjścia dla określenia pojęć związanych z przesłankami zawierania małżeństwa jest komentarz do Kodeksu rodzinnego i opiekuńczego autorstwa Krystyny Gromek (2013, Nb 2), w którym Autorka wyróżnia trzy rodzaje przesłanek: warunkujące, formalne i wykluczające ${ }^{19}$. Można je również sklasyfikować jako przesłanki dodatnie (czyli stany, które muszą istnieć, aby małżeństwo mogło być zawarte) jak i przesłanki ujemnie (czyli przeszkody niemożliwiające zawarcie małżeństwa). W analizach wykazano za pomocą jakich terminów, polskich i francuskich, są one desygnowane na poziomie leksykalno-składniowym. Analizę oparto na dwóch porównywalnych korpusach ze względu na ich gatunek i problematykę: Kodeksie rodzinnym i opiekuńczym (KRO) dla języka polskiego i Code civil (CC) dla języka francuskiego. Oba dokumenty regulują m.in. kwestie związane z zawieraniem małżeństwa, prawa i obowiązki małżonków, dlatego są one odpowiednim źródłem wiedzy terminologicznej dotyczącej przesłanek zawierania małżeństwa w prawie polskim i francuskim.

Przed dokonaniem szczegółowej analizy porównawczej terminów, przybliżona zostanie metodologia podejmowanych badań.

19 Występują one również we francuskim prawie, jednak mają one nieco odmienną systematyzację (Lamarche, Lemouland 2013). 


\section{Główne założenia metodologiczne}

Koncentrują się one wokół definicji terminologii, pojęć i terminów, które są różnie postrzegane we współczesnym językoznawstwie.

\section{Definicja terminologii}

Terminologia, jako dział językoznawstwa stosowanego, obejmuje badanie relacji pomiędzy trzema biegunami: obiektami rzeczywistości, pojęciami i terminami. Podejmowane prace terminologiczne dotyczą desygnacji pojęć w języku specjalistycznym, w szczególności w polskim i francuskim języku prawa kanonicznego i cywilnego w tym, co dotyczy związków międzyosobowych (Mazurkiewicz 2010a, $2010 \mathrm{~b}, \mathrm{w}$ druku). Takie podejście do badania języka czerpie z arystotelesowskiej triady obiekt - pojęcie - znak językowy, czyli termin. Według tej koncepcji, każdy podmiot mówiący (tu: specjalista z danej dziedziny wiedzy) obserwuje obiekty rzeczywistości, postrzega ich właściwości dzięki swoim zmysłom i intelektowi, tworząc w swoim umyśle ich obraz mentalny, a na końcu komunikuje je innym (por. Gilson 1961, Krąpiec 1995, Maryniarczyk 2011). Tak więc prezentowane badania terminologiczne biorą pod uwagę podejście referencyjne, ponieważ terminy, które będą analizowane w niniejszym artykule odwołują się do rzeczywistości prawa polskiego i francuskiego, a rolą języka naturalnego jest opisywać tę rzeczywistość. Językoznawcy-terminologowi pozostaje zbadać terminy na poziomie semantyczno-składniowym (również morfologicznym) jako środki wyrażania pojęć charakterystycznych dla danej dziedziny wiedzy i relacji pomiędzy nimi. Jeśli terminy przynależą do różnych języków naturalnych, terminolog wykaże podobieństwa i różnice w sposobie wyrażania pojęć w obrębie danej dziedziny.

\section{Od pojęć do terminów}

W terminologii pojęcie określane jest jako jednostka myśli, konstrukcja mentalna, która służy do klasyfikowania obiektów indywidualnych świata zewnętrznego i wewnętrznego przy pomocy abstrakcji bardziej lub mniej arbitralnej (dowolnej) (ISO 1987). Definicja ta pozwala na odróżnienie pojęcia od obiektu rzeczywistości, który reprezentuje. Poprzez pojęciowanie użytkownicy języka mogą strukturyzować swoją myśl i przekazywać ją innym. Aby tego dokonać, używają znaków językowych w ich formie pisemnej i ustnej. Ta koncepcja pojęcia nie zgadza się ze strukturalistycznym rozumieniem znaku językowego gdzie pojęcie (signifié, element znaczony) było nierozłącznie związane z signifiant (element znaczący). Innymi słowy, w koncepcji de Saussure'a (1916) pojęcie jest utożsamiane ze znaczeniem danego wyrazu.

Prace terminologiczne np. Depecker (2003) udowodniły, że pojęcie nie może być utożsamiane ze znaczeniem danego terminu, choć często zdarza się, że oba te wymiary pokrywają się. I tak na przykład $w$ języku polskim na wyrażenie jednego pojęcia 'mężczyzna pozostający z kobietą w związku małżeńskim' istnieją takie terminy jak mą̇, malżonek, wspótmatżonek. Z drugiej strony, biorąc pod uwagę aspekt porównawczy (choćby na osi semantycznej) języków, terminy matżeństwo i mariage 
będą nazywały pojęcia kompatybilne tylko częściowo, co zostało udowodnione wraz z Gałuskiną (Gałuskina, Mazurkiewicz 2013, 120).

Wyrażanie pojęć w języku specjalistycznym może dokonywać się na poziomie leksykalnym, gdzie konkretnym pojęciom będą odpowiadać konkretne terminy, a hierarchicznym relacjom pojęciowym (logicznym i ontologicznym) będą odpowiadać hierarchiczne relacje semantyczne (hiperonimii i holonimii). Kolejnym sposobem wyrażenia cech pojęcia $w$ języku specjalistycznym są tzw. zdania źródłowe (lub struktury predykatowo-argumentowe), których koncepcja zaczerpnięta została z gramatyki transformacyjnej Harrisa (1990). Predykacja na temat cech pojęcia wyraża się poprzez kompilację predykatu czasownikowego i odpowiadających mu argumentów w pozycji podmiotu lub dopełnienia, tworzących tzw. zdania minimalne, to znaczy takie, które nie zostały przekształcone składniowo i takie które są minimalnym nośnikiem informacji o cechach pojęcia. A wypowiedzi, które tworzą dyskurs specjalistyczny są przetworzonymi zdaniami źródłowymi.

Zasygnalizowane problemy metodologiczne jasno ukazują, że w terminologii pojmowanej jako analiza języka wyrażającego pojęcia w danej dziedzinie wiedzy, trzeba badać jednocześnie wymiar onomazjologiczny i semazjologiczny. Terminologia bowiem kompiluje $\mathrm{z}$ jednej strony analizę elementów poznawczych, niezależnych i uprzednich w stosunku do systemów językowych, a z drugiej funkcjonowanie semantycznoskładniowe terminów wyrażających poszczególne koncepty w korpusach specjalistycznych.

\section{Przesłanki zawarcia małżeństwa}

Jak to już wcześniej zostało zasygnalizowane, przesłanki to okoliczności, warunki potrzebne do zawarcia małżeństwa. Gromek (2013), stosując utrwalony już podział w prawie polskim, wyróżniła wśród nich warunkujące, formalne i wykluczające.

\section{Desygnacja przesłanek warunkujących}

Przesłanki warunkujące są konieczne i wystarczające do zawarcia małżeństwa. Mówiąc o nich, Gromek (ibid.) wyróżnia takie pojęcia jak: 'płeć nupturientów', ‘jednoczesność oświadczeń woli' i 'złożenie oświadczenia woli przed podmiotem uprawnionym'. Przez jakie środki wyrażone są one $\mathrm{w}$ językach polskim i francuskim?

i) 'płeć nupturientów'

Na podstawie fragmentu KRO:

Przykład 1.

Małżeństwo zostaje zawarte, gdy mężczyzna i kobieta jednocześnie obecni złożą przed kierownikiem urzędu stanu cywilnego oświadczenia, że wstępują ze sobą $\mathrm{w}$ związek małżeński. (art. 1. § 1. KRO) 
Paulina MAZURKIEWICZ, Przesłanki zawarcia małżeństwa w prawie Polskim...

można zauważyć, że pojęcie 'płeć nupturientów' wyraża się leksemami mężczyzna i kobieta. W prawie polskim małżeństwo może być zawarte tylko pomiędzy osobami różnej płci. Kodeks rodzinny i opiekuńczy realizuje w tym zakresie zasadę wyrażoną w Konstytucji Rzeczypospolitej Polskiej w jej art. 18, zgodnie z którym: „Małżeństwo jako związek kobiety i mężczyzny, rodzina, macierzyństwo i rodzicielstwo znajdują się pod ochroną i opieką Rzeczypospolitej Polskiej”. prawnym.

Pojęcie 'płeć nupturientów' wyraża się inaczej we francuskim języku

Przykład 2.

Le mariage est contracté par deux personnes de sexe différent ou de même sexe. (art. 143. CC)

Nie pojawiają się tutaj odpowiedniki leksemów mężczyzna i kobieta (un homme et une femme), tylko deux personnes de sexe différent ou de même sexe ('dwie osoby różnej lub tej samej płci’), ponieważ prawo francuskie dopuszcza zawieranie małżeństw zarówno hetero- jak i homoseksualnych. Wydaje się, że leksemy w języku polskim mają sens bardziej szczegółowy niż te $\mathrm{w}$ języku francuskim, jako że posiadają cechę różnicującą płeć osoby. Podobnie ma się rzecz z polskim terminem nupturient ('osoba, która zamierza zawrzeć związek małżeński') ${ }^{20}$, pochodzącym od łacińskiego nupturiens, którego odpowiednikiem $\mathrm{w}$ języku francuskim jest futur époux, termin o znaczeniu bardziej ogólnym.

ii) ‘jednoczesność oświadczeń woli’, złożonych osobiście przez nupturientów

Przykład 3.

Małżeństwo zostaje zawarte, gdy mężczyzna i kobieta jednocześnie obecni złożą przed kierownikiem urzędu stanu cywilnego oświadczenia, że wstępują ze sobą w związek małżeński. (art. 1. § 1 . $\mathrm{KRO})$

Można tutaj wyróżnić zdania źródłowe wyrażające cechy pojęcia 'jednoczesność oświadczeń woli', czyli:

- 'mężczyzna i kobieta są jednocześnie obecni',

- 'mężczyzna i kobieta jednocześnie składają oświadczenie woli',

Temu paragrafowi odpowiada francuskie wypowiedzenie o znaczeniu przeczącym.

$20 \quad$ sjp.pwn.pl. 


\section{Przykład 4.}

Il n'y a pas de mariage lorsqu'il n'y a point de consentement. (art. 146. CC)

Kolejny raz nie pojawia się tutaj rozróżnienie płci nupturientów, a agens jest wyrażony jedynie implicytnie. Warto również zwrócić uwagę na wieloznaczność francuskiego terminu mariage wyrażającego $\mathrm{z}$ jednej strony związek między dwiema osobami (małżeństwo), a z drugiej czynność zawierania małżeństwa (powyższy przykład), ze względu na pochodzenie od czasownika se marier (Mazurkiewicz 2010, 332). Natomiast polski termin małżeństwo występuje zawsze w funkcji argumentu predykatu czasownikowego zawierać, zawrzeć lub jego formy nominalnej zawieranie, zawarcie.

Oba systemy prawne przewidują wyjątek od przesłanki jednoczesności oświadczeń woli, jakim jest możliwość zawarcia małżeństwa per procura, czyli przez pełnomocnika.

\section{Przykład 5.}

Z ważnych powodów sąd może zezwolić, żeby w oświadczenie o wstąpieniu w związek małżeński lub oświadczenie przewidziane w art. $1 \S 2$ zostało złożone przez pełnomocnika. (art. $6 . \S 1$. KRO)

Na tej podstawie można wyróżnić w zdaniu źródłowym:

- '[ktoś] składa oświadczenie woli'

argument pełnomocnik, który, tak jak leksemy mężczyzna i kobieta, pełni rolę agensa. Po przekształceniu wypowiedzenia, powyższe zdanie źródłowe brzmiałoby następująco:

- 'pełnomocnik składa oświadczenie woli'.

analogicznie do zdania:

- 'mężczyzna i kobieta jednocześnie składają oświadczenie woli'.

Odpowiednikiem francuskim terminu małżéstwo per procura jest termin mariage par procuration (Lamarche, Lemouland 2013). Francuski termin powstał w wyniku naturalizacji, czyli dostosowywania słów do francuskich zasad fonetyki i morfologii, natomiast polski termin ma zachowany element łaciński jako specyfikujący znaczenie terminu małżeństwo. Z powyższego wynika, że termin małżeństwo per procura jest hybrydą językową, ponieważ zawiera elementy pochodzące z różnych języków (tutaj: polskiego i łacińskiego). Oba terminy, poprzez swoje specyficzne znaczenie stają się odpowiednio hiponimami terminów małżeństwo i mariage.

Prawo francuskie dopuszcza również możliwość zawarcia małżeństwa z osobą zmarłą jako inny wyjątek od reguły jednoczesnego złożenia oświadczenia woli. 
Paulina MAZURKIEWICZ, Przesłanki zawarcia malżeństwa w prawie Polskim...

Przykład 6.

Le Président de la République peut, pour des motifs graves, autoriser la célébration du mariage en cas de décès de l'un des futurs époux, dès lors qu'une réunion suffisante de faits établit sans équivoque son consentement. (art. 171. CC)

Termin-hiponim mariage posthume (Lamarche, Lemouland 2013) wyraża to pojęcie. W języku polskim nie ma on odpowiednika, gdyż prawo polskie nie przewiduje zaistnienia takiej okoliczności. Znamiennym jest fakt, że osoba zawierająca taki związek staje się natychmiast wdową lub wdowcem. Aby to małżeństwo było ważne, potrzebny jest dowód na to, że osoba zmarła wyrażała chęć zawarcia małżeństwa. uprawniony'.

Ostatnia przesłanka warunkująca wyrażona jest pojęciem 'podmiot

iii) ‘podmiot uprawniony’ do odebrania od nupturientów zgodnych oświadczeń woli.

Wyrażenie rzeczownikowe podmiot uprawniony jest hiperonimem terminów: kierownik urzędu stanu cywilnego (por. art. 1. § 1., art. 9. § 1. KRO), duchowny (por. art. 1. § 2. i 3., art. 9. § 2. KRO), polski konsul (art. 1. § 4. KRO). W prawie francuskim, uznaje się jedynie zawarcie małżeństwa przed urzędnikiem państwowym (officier de l'état civil), jak o tym mówi art. 165. CC. Innymi słowy, prawo francuskie nie przewiduje religijnej formy zawierania małżeństwa jak to ma miejsce w naszym systemie prawnym.

\section{Przykład 7.}

Le mariage sera célébré publiquement lors d'une cérémonie républicaine par l'officier de l'état civil de la commune dans laquelle l'un des époux, ou l'un de leurs parents, aura son domicile ou sa résidence à la date de la publication prévue par l'article 63, et, en cas de dispense de publication, à la date de la dispense prévue à l'article 169ci-après. (art. 165. CC)

Inne 'podmioty uprawnione' do odebrania oświadczeń woli są desygnowane przez terminy autorités diplomatiques ou consulaires françaises, jak to można zauważyć w art. 171-1. CC:

\section{Przykład 8.}

Le mariage contracté en pays étranger entre Français, ou entre un Français et un étranger, est valable s'il a été célébré dans les formes usitées dans le pays de célébration et pourvu que le ou les Français n'aient point contrevenu aux dispositions contenues au chapitre $\mathrm{I}^{\text {er }}$ du présent titre. Il en est de même du mariage célébré par les autorités diplomatiques ou consulaires françaises, conformément aux lois françaises. Toutefois, ces autorités ne peuvent procéder à la célébration du mariage entre un 
Français et un étranger que dans les pays qui sont désignés par décret. (art. 171-1. CC)

Z powyższych analiz wynika, że pojęcie 'podmiot uprawniony do odebrania oświadczeń woli' ma węższy zasięg w systemie prawa francuskiego, ponieważ nie uwzględnia szczegółowego pojęcia 'duchowny', obecnego w systemie prawa polskiego.

Podsumowując paragraf dotyczący desygnacji przesłanek warunkujących, nasuwają się dwa podstawowe wnioski o charakterze kontrastywnym. Po pierwsze, to samo pojęcie 'płeć nupturientów' posiada desygnaty o różnym zasięgu w polskim i francuskim języku prawa. W języku francuskim można wyraźnie wskazać na użycie hiperonimów personne czy époux (ewentualnie futur époux) bez rozróżnienia płci, odmiennie niż to ma miejsce w polskim języku prawa, w którym wyraźnie zaznacza się terminy wskazujące mężczyznę i kobietę jako osoby uprawnione do zawarcia małżeństwa. Po drugie, hiponimy terminów małżeństwo / mariage desygnują specyficzne warunki zawierania małżeństwa, jak na przykład małżéstwo przez pełnomocnika / mariage par procuration. Czasem są one charakterystyczne tylko dla jednego systemu prawnego, jak choćby mariage posthume. Jest też faktem, że francuskie prawo nie uwzględnia sytuacji, w której duchowny może odbierać oświadczenie woli zawarcia małżeństwa (por. termin małżeństwo wyznaniowe). Reasumując, każdy system prawny posiada swoje specyficzne pojęcia i terminy, które nie zawsze mają odpowiedniki w drugim języku.

\section{Desygnacja przesłanek formalnych}

Przesłanki formalne są desygnowane przez terminy wyrażające ogólne kategorie pojęciowe, takie jak 'dokumenty', 'osoby', 'czynności'.

Pierwsza kategoria pojęciowa jest wyrażona poprzez terminy oznaczające dokumenty przedślubne i zaświadczenia wydawane po zawarciu małżeństwa.

i) dokumenty przedślubne / pièces ou indications

\section{Przykład 9.}

Osoby zamierzające zawrzeć małżeństwo powinny złożyć lub przedstawić kierownikowi urzędu stanu cywilnego dokumenty niezbędne do zawarcia malżeństwa, określone w odrębnych przepisach. (art. 3. $\S 1$. KRO)

\section{Przykład 10.}

(...) la célébration du mariage est subordonnée :

$1^{\circ}$ A la remise, pour chacun des futurs époux, des indications ou pièces suivantes :

- les pièces exigées par les articles 70 ou 71 ; 
Paulina MAZURKIEWICZ, Przesłanki zawarcia małżeństwa w prawie Polskim...

- la justification de l'identité au moyen d'une pièce délivrée par une autorité publique ;

- l'indication des prénoms, nom, date et lieu de naissance, profession et domicile des témoins, sauf lorsque le mariage doit être célébré par une autorité étrangère (...) (art. 63. CC)

Przykład 11.

La copie intégrale de l'acte de naissance remise par chacun des futurs époux à l'officier de l'état civil qui doit célébrer leur mariage ne doit pas dater de plus de trois mois si elle a été délivrée en France et de plus de six mois si elle a été délivrée dans un consulat. (art. 70. CC)

\section{Przykład 12.}

Celui des futurs époux qui serait dans l'impossibilité de se procurer cet acte pourra le suppléer en rapportant un acte de notoriété délivré par un notaire ou, à l'étranger, par les autorités diplomatiques ou consulaires françaises compétentes. (art. 71. CC)

Można zauważyć, że KRO nie wskazuje bezpośrednio, jakie dokumenty są potrzebne do zawarcia małżeństwa. Nie podaje również odniesienia do przepisów wskazujących na owe dokumenty. Natomiast francuski CC wyraźnie podaje terminy desygnujące niezbędne dokumenty potrzebne do zawarcia małżeństwa: pièces ou indications. Termin pièce jest hiperonimem terminów: pièce d'identité ('dowód tożsamości'), copie intégrale de l'acte de naissance ('pełny odpis aktu urodzenia'), acte de notoriété ('akt notarialny'). Ostatni hiponim desygnuje dokument niezbędny w wypadku, gdy nupturient nie może dostarczyć pełnego odpisu aktu urodzenia. Termin indication jest predykatem rzeczownikowym kondensującym zdanie źródłowe 'quelqu'un indique quelque chose' ('ktoś wskazuje coś'), a w przypadku przykładu 10., chodzi o predykację: 'ktoś wskazuje imiona, nazwisko, datę, miejsce urodzenia, zawód i miejsce zamieszkania świadków'. Agens w tym wypowiedzeniu jest implicytny, jednak można się domyślać, że wyraża on nupturientów.

Kolejna kategoria dokumentów jest wskazana przez terminy:

ii) zaświadczenie / certificat

\section{Przykład 9.}

Osobom zamierzającym zawrzeć małżeństwo w sposób określony w art. 1 § 2 i 3 kierownik urzędu stanu cywilnego wydaje zaświadczenie stwierdzające brak okoliczności wyłączających zawarcie małżeństwa oraz treść i datę złożonych przed nim oświadczeń w sprawie nazwisk przyszłych małżonków i ich dzieci. (art. 4[1] .§1. KRO) 
Przykład 10.

Si la publication a été faite dans plusieurs communes, l'officier de l'état civil de chaque commune transmettra sans délai à celui d'entre eux qui doit célébrer le mariage un certificat constatant qu'il n'existe point d'opposition. (art. 69. CC).

iii) zaświadczenie (wydane przez duchownego) / ----

Przykład 11.

Niezwłocznie po złożeniu oświadczeń, o których mowa w $§ 1$, duchowny sporządza zaświadczenie stwierdzające, że oświadczenia zostały złożone w jego obecności przy zawarciu związku małżeńskiego podlegającego prawu wewnętrznemu kościoła albo innego związku wyznaniowego. Zaświadczenie to podpisują duchowny, małżonkowie i dwaj pełnoletni świadkowie obecni przy złożeniu tych oświadczeń. (art. 8. § 2. KRO).

Zauważyć można, że terminy zaświadczenie i certificat są predykatami nominalnymi kondensującymi zdania źródłowe: 'ktoś zaś wiadcza coś', i ‘quelqu’un certifie quelque chose'. W obu przypadkach, agens będzie wskazywał na urzędnika stanu cywilnego (kierownika urzędu), a obiekt tych zdań wskazuje na brak okoliczności wyłączających zawarcie małżeństwa ('opposition au mariage'). System prawa polskiego wymaga również w art. 4 [1] $\S 1$ KRO podania nazwisk przyszłych małżonków i ich dzieci. W przykładzie 11., w kontekście religijej formy zawierania małżeństwa, pojawia się jeszcze jeden agens, który wskazuje na duchownego. Termin zaświadczenie jest w polskim języku prawnym argumentem predykatów wydawać i sporządzać. Natomiast w języku francuskim termin certificat jest argumentem predykatu transmettre ('przekazać'). Powyższe predykaty czasownikowe pochodzące z języka ogólnego w połączeniu $\mathrm{z}$ w/w argumentami zyskują swoje specyficzne, prawne znaczenie. 'świadek'.

Kolejna kategoria przesłanek formalnych wskazana jest przez pojęcie

iv) dwóch pełnoletnich świadków / (au moins) deux témoins ou quatre témoins (au plus)

\section{Przykład 12.}

Jeżeli małżeństwo jest zawierane przed kierownikiem urzędu stanu cywilnego, oświadczenia o wstąpieniu w związek małżeński powinny być złożone publicznie w obecności dwóch pelnoletnich świadków. ( art. 7. § 1. KRO).

\section{Przykład 13.}

Le jour désigné par les parties, après le délai de publication, l'officier de l'état civil, à la mairie, en présence d'au moins deux témoins, ou de 
Paulina MAZURKIEWICZ, Przesłanki zawarcia małżeństwa w prawie Polskim...

quatre au plus, parents ou non des parties, fera lecture aux futurs époux des articles 212_et 213, du premier alinéa des articles 214 et 215, et de l'article 371-1 du présent code. (art. 75. CC)

Cecha semantyczna polskiego terminu świadek to 'pełnoletni', natomiast w przypadku jego odpowiednika francuskiego 'témoins' to 'parent ou non', czyli 'krewny lub nie'. Tak więc oba systemy prawne odmiennie profilują te znaczenie tych leksemów. Różnice pojawiają się również w liczbie świadków uczestniczących w ceremonii zawarcia małżeństwa. W prawie polskim chodzi o liczbę dwóch świadków, natomiast w prawie francuskim liczba ta może się rozciągnąć do czterech.

Kolejna kategoria pojęciowa przesłanek formalnych wyrażona jest przez terminy oświadczenie / déclaration.

v) oświadczenie osób zawierających małżeństwo o wstapieniu w zwiqzek malżeński I déclaration des parties de vouloir se prendre pour époux

Przykład 14.

Każda z osób zawierających małżeństwo składa oświadczenie o wstąpieniu w związek malżeński, powtarzając za kierownikiem urzędu stanu cywilnego treść oświadczenia lub odczytując je na głos. Osoba nie mogąca mówić składa oświadczenie o wstąpieniu w związek małżeński podpisując akt małżeństwa. (art. 7. § 3. KRO)

Przykład 15.

Il [1'officier de l'état civil, PM ] recevra de chaque partie, l'une après l'autre, la déclaration qu'elles veulent se prendre pour époux : il prononcera, au nom de la loi, qu'elles sont unies par le mariage, et il en dressera acte sur-le-champ. (art. 75. CC)

W powyższych przykładach terminy oświadczenie / déclaration są predykatami nominalnymi i kondensują zdania źródłowe 'ktoś oświadcza, że P', a także 'quelqu'un déclare que P'. Symbol P oznacza zdanie podrzędne 'ktoś wstępuje w związek małżeński' i 'quelqu'un veut se prendre pour époux'. Agens $w$ tych zdaniach jest wyrażony leksemami osoby i parties ('strony'). KRO precyzuje sposób składania oświadczenia poprzez imiesłowy: powtarzając, odczytujac, podpisując.

Ostatnia przesłanka formalna wyrażona jest przez termin ogłoszenie, którego odpowiednik $\mathrm{w}$ języku francuskim nie ma formy rzeczownikowej, tylko zdanie źródłowe 'quelqu'un prononce que P' ('ktoś ogłasza, że P).

vi) ogłoszenie przez kierownika urzędu stanu cywilnego, że małżéstwo zostało zawarte / l'officier de l'état civil prononce que les parties sont unies par le mariage 
Przykład 16.

Po złożeniu oświadczeń o wstąpieniu w związek małżeński przez obie strony kierownik urzędu stanu cywilnego ogłasza, że wskutek zgodnych oświadczeń obu stron malżeństwo zostało zawarte. (art. 7. § 4. KRO)

Przykład 17.

[...] il [l'officier de l'état civil, PM] prononcera, au nom de la loi, qu'elles [les parties, $\mathbf{P M}$ ] sont unies par le mariage, et il en dressera acte sur-le-champ. (art. 75. CC)

Polski termin ogłoszenie jest predykatem nominalnym kondensującym zdanie źródłowe 'ktoś ogłasza, że P', mającym to samo znaczenie i konstrukcję jak francuskie zdanie 'quelqu'un prononce que P'. Symbol P oznacza zdanie źródłowe podrzędne 'obie strony zawierają małżeństwo', 'les parties s'unissent par le mariage'. Na podstawie przykładu 16. można zauważyć, że polskie prawo precyzyjnie określa okoliczności uznania ważności małżeństwa jako skutku zgodnych oświadczeń obu stron. W kodeksie francuskim nie zaznaczono wyraźnie tego skutku.

Ostatnia przesłanka formalna dotyczy ceremoniału religijnego w przypadku wyznaniowej formy zawarcia małżeństwa, tzw. małżeństwa konkordatowego. Jak to zostało wcześniej zaznaczone, jest to forma uznawana jedynie przez system prawa polskiego.

Według Gromek (2013, Nb 2), przesłanki formalne służą konkretnym celom, takim jak:

i) ujednolicenie trybu postępowania,

ii) zapobieganie zawierania małżeństw nieakceptowanych przez prawo,

iii) podkreślenie doniosłości społecznej,

iv) nadanie uroczystego charakteru.

Cele te również są realizowane $\mathrm{w}$ przypadku formy zawarcia małżeństwa $\mathrm{w}$ prawie francuskim.

Z przytoczonych przykładów wynika, że terminy polskie i francuskie desygnujące przesłanki formalne często sobie odpowiadają. W analizach wykazano uściślenia terminologiczne co do wymaganych dokumentów (podanie nazwisk przyszłych małżonków i ich dzieci, por. art. 4[1]. § 1. KRO), czy okoliczności uznania ważności małżeństwa (por. art. 7. § 4. KRO). Zasadnicze różnice w pojęciowaniu przesłanek formalnych występują jedynie w sytuacjach, w których terminy wskazują na wyznaniową formę zawarcia małżeństwa cywilnego aprobowaną jedynie przez prawo polskie lub desygnują pojęcie 'świadek'. 
Paulina MAZURKIEWICZ, Przesłanki zawarcia małżeństwa w prawie Polskim...

\section{Desygnacja przesłanek wykluczających}

Przesłanki wykluczające określane są również jako przeszkody małżeńskie. Wyrażone są one w art. 10-16 KRO. Zasadniczo zaobserwować można wyrażenie przesłanek wykluczających poprzez zdanie źródłowe:

- ' [ktoś] nie może zawrzeć małżeństwa'.

Leksemy w pozycji podmiotu (agens) są następujące:

- osoba nie majaca ukończonych lat osiemnastu (art. 10. § 1. KRO)

- osoba ubezwłasnowolniona całkowicie (art. 11. § 1. KRO)

- osoba dotknięta choroba psychiczna albo niedorozwojem umysłowym (art. 12. § 1. $\mathrm{KRO})$

- $\quad$ kto już pozostaje w związku małżeńskim (art. 13. § 1. KRO)

- krewni w linii prostej, rodzeństwo ani powinowaci w linii prostej (art. 14. § 1. $\mathrm{KRO})$

Powyższe terminy organizują się w kategoriach pojęciowych 'osoba', 'ktoś', 'krewni', bez rozróżnienia płci, i wyznaczają tym samym kategorie hiperonimów określonych przez zdania źródłowe wskazujące na konkretne ograniczenia uniemożliwiające zawarcie małżeństwa: 'osoba nie ma ukończonych lat osiemnastu', 'osoba jest ubezwłasnowolniona całkowicie', 'osoba jest dotknięta chorobą psychiczną', 'osoba jest dotknięta niedorozwojem umysłowym', 'ktoś pozostaje w związku małżeńskim', 'ktoś jest krewny', 'ktoś jest rodzeństwem', 'ktoś jest powinowatym w linii prostej'.

Podobne przesłanki wykluczające odnajdujemy we francuskim Kodeksie cywilnym. Są one jednak inaczej wyrażone, tzn. zasadniczo poprzez strukturę predykatowoargumentową:

- '(ne pas) contracter mariage',

- 'prohiber mariage',

- 'il n'y a pas mariage',

ale bez wyraźnie zaznaczonego agensa, jak to miało miejsce w powyższych przykładach z KRO:

Przykład 18.

Le mariage ne peut être contracté avant dix-huit ans révolus. (art. 144. $\mathrm{CC})$

Przykład 19.

On ne peut contracter un second mariage avant la dissolution du premier. (art. 147. CC)

Zdarza się również, że agens jest eksplicytnie wyrażony: 
Przykład 20.

Les mineurs ne peuvent contracter mariage sans le consentement de leurs père et mère ; en cas de dissentiment entre le père et la mère, ce partage emporte consentement. (art. 148. CC)

\section{Przykład 21}

En ligne directe, le mariage est prohibé entre tous les ascendants et descendants et les alliés dans la même ligne. (art. 161. CC)

\section{Przykład 22.}

En ligne collatérale, le mariage est prohibé, entre le frère et la soeur, entre frères et entre sœurs. (art. 162. CC)

Przykład 23.

Le mariage est prohibé entre l'oncle et la nièce ou le neveu, et entre la tante et le neveu ou la nièce. (art. 163. CC)

Można zauważyć, że oba systemy prawne formułują desygnację przesłanek wykluczających w sposób analogiczny. Odnotować warto jednakże kilka różnic leksykalnych. Zdanie źródłowe 'osoba nie ma ukończonych lat osiemnastu' ma swój odpowiednik we francuskim terminie mineur ('małoletni', por. przykład 20.), a leksem rodzeństwo ma swój odpowiednik w wyrażeniu le frère et la soeur i leksemach frères, sœurs (przykład 22.) biorąc pod uwagę fakt, że w języku francuskim nie ma innego określenia na ten rodzaj relacji rodzinnych. Natomiast leksemy takie jak krewni, powinowaci w linii prostej, również mają odpowiedniki w leksemach les ascendants et descendants et les alliés dans la même ligne. (przykład 21.). Francuski Code civil doprecyzowuje również niemożność zawarcia małżeństwa pomiędzy wuj(ki)em a siostrzenicą / bratanicą, siostrzeńcem / bratankiem, jak również pomiędzy ciotką a siostrzenicą / bratanicą, siostrzeńcem / bratankiem (przykład 23.).

\section{Wnioski}

Analiza porównawcza terminów oznaczających przesłanki zawarcia małżeństwa w prawie polskim i francuskim wykazała, że są one porównywalne. Studium desygnacji przesłanek formalnych i wykluczających ukazało wiele zbieżności semantycznoskładniowych terminów. Wykazano jednakże różnice w zdaniach źródłowych, gdzie argument $\mathrm{w}$ roli agensa jest o wiele bardziej eksplicytny w Kodeksie rodzinnym i opiekuńczym niż w Code civil. Oba dokumenty ukazują problem kondensacji zdań źródłowych poprzez użycie predykatów nominalnych, co jest cechą charakterystyczną języka prawa. 
Paulina MAZURKIEWICZ, Przesłanki zawarcia małżeństwa w prawie Polskim...

Największe różnice terminologiczne zaobserwowaliśmy badając terminy oznaczające przesłanki warunkujące. Wynikają one $\mathrm{z}$ różnego pojęciowania instytucji małżeństwa, bowiem polski termin małżeństwo desygnuje tylko i wyłącznie związek mężczyzny i kobiety składających jednoczesne oświadczenie woli (z wyjątkiem terminu małżeństwo per procura) z dopuszczeniem formy wyznaniowej. Natomiast francuski odpowiednik mariage ma zakres nieco inny, bo obejmuje również desygnowanie małżeństwa homoseksualnego czy też tzw. mariage posthume, czyli małżeństwo $\mathrm{z}$ osobą zmarłą. Prawo francuskie uznaje jedynie formę małżeństwa zawartego przed urzędnikiem państwowym, nie dopuszczając tym samym formy wyznaniowej, jak to ma miejsce w prawie polskim.

Podejmowane analizy są dowodem na to, że relacje językowe paradygmatyczne czy syntagmatyczne wynikają bezpośrednio z relacji konceptualnych i je wyrażają. Sama zaś instytucja małżeństwa, pomimo czasem zasadniczych różnic $w$ jej postrzeganiu, jest uniwersalna i nadal cieszy się przychylnością prawa polskiego i francuskiego. 


\section{Bibliografia}

Depecker, Loïc. 2009. Entre signe et concept : éléments de terminologie générale. Paris: Presses de la Sorbonne nouvelle.

De Saussure, Ferdinand. 1916. Cours de linguistique générale. Paris: Payot.

Gałuskina, Ksenia, i Paulina Mazurkiewicz. 2013. Expression du concept 'mariage' en droit français et 'małżeństwo' en droit polonais. Étude de corpus. Roczniki Humanistyczne nr LXI, 8, ss. 111-129.

Gilson, Etienne. 1961. Linguistique et philosophie. Essais sur les constantes philosophiques du langage. Paris: Vrin.

Gromek, Krystyna. 2013. Kodeks rodzinny i opiekuńczy. Komentarz. wyd. 4. Warszawa: C. H. Beck.

Harris, Zellig. 1990. La genèse de l'analyse des transformations et de la métalangue. Langages nr 99, ss. 9-20.

ISO 1087. 1990. Terminologie - Vocabulaire.Genève: Organisation internationale de normalisation.

Krąpiec, Mieczysław Albert. 1995. Dzieła. Język i świat realny, XIII. Lublin: RW KUL. Lamarche, Marie, i Jean-Jacques Lemouland. 2013. Mariage. Conditions de formation. Répertoire Dalloz. www.dalloz.fr. (data dostępu 05.09.2014).

Maryniarczyk, Andrzej. 2011. Rola języka naturalnego w metafizyce realistycznej. Roczniki Humanistyczne nr LIX, 8, ss. 7-22.

Mazurkiewicz, Paulina. 2010a. La construction du sens du terme famille en français et rodzina en polonais dans la Charte des Droits de la Famille. W Wybrane problemy terminologii polsko-francuskich i metod badań językoznawczych W tłumaczeniach, red. Dorota Śliwa, ss. 117-133. Lublin: KUL.

Mazurkiewicz, Paulina. 2010b. La terminologie française et polonaise du mariage: entre le présupposé existentiel et les moyens linguistiques d'expression du concept. Des mots et du texte aux conceptions de la description linguistique, red. Anna Dutka-Mańkowska, Teresa Giermak-Zielińska, ss. 342-350. Warszawa: UW.

Mazurkiewicz, Paulina. 2012. Vers de nouvelles perspectives de la recherche terminologique en Pologne. Romanica Cracoviensia, nr 11, ss. 282-291.

Mazurkiewicz, Paulina, w druku. La relation concept - terme sur l'exemple de la terminologie du mariage dans le Code de Droit Canonique. RILA (Rassegna italiana di linguistica applicata).

Siedlecki, Władysław, Świeboda, Zdzisław. 2000. Postępowanie cywilne. Zarys wykładu, wyd. 2 zmienione. Warszawa: Wydaw. Prawnicze PWN.

\section{Źródla}

Code civil. www.legifrance.gouv.fr (data dostępu 10.09.2014 ).

Kodeks rodzinny i opiekuńczy. www.isap.sejm.gov.pl (data dostępu 11.09.2014 ).

Konstytucja Rzeczypospolitej Polskiej. www.sejm.gov.pl/prawo/konst/polski/kon1.htm (data dostępu 14.09.2014).

Słownik języka polskiego. sjp.pwn.pl (data dostępu 10.09.2014 ). 